\title{
A comparison of the availability and ileal digestibility of lysine in cottonseed and soya-bean meals for grower/finisher pigs
}

\author{
BY E. S. BATTERHAM, L. M. ANDERSEN, D. R. BAIGENT \\ AND R. E. DARNELL* \\ NSW Agriculture and Fisheries, North Coast Agricultural Institute, Wollongbar, \\ New South Wales 2480, Australia \\ AND M. R. TAVERNER \\ Department of Agriculture and Rural Affairs, Animal Research Institute, Werribee, Victoria 3030 , \\ Australia
}

(Received 28 February 1990 - Accepted 30 March 1990)

\begin{abstract}
The availability of lysine and the ileal digestibility of amino acids in three cottonseed meals and a soyabean meal for grower/finisher pigs were determined. The usefulness of the availability estimates for formulating diets was assessed. The availability of lysine, as assessed with a slope-ratio assay, was (proportion of total): cottonseed meal no. $1,0.27$; no. $2,0.30 ;$ no. $3,0.29$; soya-bean meal, 0.90 . Ileal digestibility of lysine in the meals (proportion of total) was: cottonseed meal no. 1, 0.58; no. 2, 0.68; no. $3,0.72$; soya-bean meal, 0.89 . Pigs given diets formulated to the same available lysine concentration grew at similar rates and retained the same amount of lysine in the carcasses. The results indicate that, for meals of high availability (soya-bean meal), reduced ileal digestibility appears to be the main reason for reduced availability. However, in meals of low availability (cottonseed meal), reduced ileal digestibility only accounts for part of the reduced availability. Thus, the ileal digestibility of lysine is not a reliable indicator of lysine availability.
\end{abstract}

Lysine: Ieal digestibility: Availability : Cottonseed meal: Soya-bean meal: Pigs

Previous work (Batterham et al. 1979, 1984) indicated that the availability of lysine in cottonseed meal, as assessed by slope-ratio assays, was low for pigs $(0 \cdot 39-0 \cdot 43)$. This was in contrast to soya-bean meal, where lysine availability was high (0.84-0.98). The low lysine availability in cottonseed meal is presumably due to the processing conditions used in the extraction of oil and inactivation of the toxin, gossypol. It is necessary to formulate diets on an available lysine basis to take into account the large difference in availability for growing pigs that occurs between the different protein concentrates.

Slope-ratio assays are time-consuming and expensive to conduct and interest has centred on the use of the ileal digestibility assay to estimate amino acid availability. This assay also has the advantage over slope-ratio assays in that the digestibility of all amino acids can be assessed at the same time and only small numbers of pigs are required per assay. The assumption is made that, if an amino acid is not recovered at the terminal ileum, then it has been absorbed in a form suitable for utilization. This assumption is not strictly correct, as amino acids can be absorbed in forms that are not efficiently utilized (e.g. $\epsilon$ - $N$-propionylL-lysine in rats (Bjarnason \& Carpenter, 1969)). Thus, ileal digestibility can overestimate availability.

Despite the interest in these assays, there have been few studies of the relationship between ileal digestibility and lysine availability. In comparative studies with one sample of lupin (Lupinus albus)-seed meal, the ileal digestibility of lysine for finisher pigs $(0 \cdot 86$;

* Present address: Agricultural Research and Advisory Station, Grafton, New South Wales 2460, Australia. 
M. R. Taverner, personal communication) was considerably higher than lysine availability for growing pigs ( $0 \cdot 37$; Batterham et al. 1984). In contrast, values for soya-bean meal have been high by both techniques (ileal digestibility 0.89 ; Taverner, 1982; lysine availability 0.84 0.98; Batterham et al. 1979, 1984).

With slope-ratio assays, the estimate of availability varies with the response criterion chosen. Batterham et al. (1984) reported that food conversion efficiency (FCE) on a carcass basis was the most appropriate criterion of response, as it took into account differences in both food intake and gut contents. In using carcass gain as a response criterion, it is assumed that the rate of lean deposition is similar with each lysine increment. This was confirmed by assessing the lean content of the hams. The criterion of protein deposition in the carcass should be the same as, or more sensitive than, carcass gain. However, Batterham et al. (1986) reported that there was no consistent relationship between these two variables for five meals and that values based on FCE on a carcass basis appeared to be more applicable in a subsequent growth experiment with two of the meals.

The present paper reports experiments designed to investigate the relationship between the availability and ileal digestibility of lysine in three cottonseed meals and a soya-bean meal for pigs. The opportunity was taken with the slope-ratio assay to investigate further the relative merits of FCE and protein deposition as variables of response and to determine if differences in energy retention by the pigs influenced the assay values. The usefulness of the slope-ratio values in dietary formulations for grower pigs was assessed.

\section{EXPERIMENTAL}

Protein concentrates. The composition of the wheat, wheat gluten and four protein concentrates are presented in Table 1. Cottonseed meals nos. 1 and 2 were 'prepress' solvent extracted and cottonseed meal no. 3 was expeller extracted. The soya-bean meal was 'prepress' solvent extracted.

\section{Expt 1. Slope-ratio assay for lysine availability}

The slope-ratio assay was used to assess lysine availability in the four protein concentrates. Diets were formulated to contain graded levels of standard (free) and test lysine. Linear regression coefficients of response (for example, of FCE) to increasing dose level of test protein and standard lysine were calculated and the ratio of the linear regression coefficients, test protein:standard lysine, provided the estimate of availability of the lysine in the test protein. The dose levels for the test proteins were formulated to contain the same total lysine as that of the standard lysine doses so that the estimate of lysine in the test protein was an expression of lysine availability.

In the statistical analyses of the slope-ratio assay, there are a number of criteria to be tested to try to ensure that the responses are due to the test amino acid and are not influenced by other dietary factors (Finney, 1964). The response to the standard amino acid is examined to determine if it passes through the basal diet (designated blanks). Similarly, the responses to both the standard amino acid and the test proteins are also examined for intersection and to determine if there is any curvature (quadratic, etc.) in the responses. The latter could be due to either depressing (if negative curve) or stimulating (if positive curve) effects of nutrients contributed by the test protein. If the previously described tests are not significant, then the responses are considered statistically valid and the potency estimates calculated. The analysis of variance is as shown in Table 2.

Diets. The four protein concentrates were assayed in the one experiment. This involved the use of twenty-one diets: the basal diet (blank), four diets to determine the pigs' response to standard lysine, and sixteen for the four protein concentrates (four for each protein). The basal diet contained $(\mathrm{g} / \mathrm{kg})$ : wheat 650 , wheat gluten 100 , L-lysine monohydrochloride 1.49 , 
Table 1. Composition $(\mathrm{g} / \mathrm{kg})$ of the wheat, wheat gluten and four protein concentrates

\begin{tabular}{|c|c|c|c|c|c|c|}
\hline & \multirow[b]{2}{*}{ Wheat } & \multirow{2}{*}{$\begin{array}{l}\text { Wheat } \\
\text { gluten }\end{array}$} & \multicolumn{3}{|c|}{ Cottonseed meal } & \multirow{2}{*}{$\begin{array}{c}\text { Soya-bean } \\
\text { meal }\end{array}$} \\
\hline & & & No. 1 & No. 2 & No. 3 & \\
\hline Crude protein (nitrogen $\times 6.25$ ) & 168 & 775 & 361 & 360 & 445 & 425 \\
\hline Dry matter & 916 & 913 & 912 & 896 & 952 & 896 \\
\hline Light petroleum (b.p. $40-60^{\circ}$ ) extract & 16 & 4 & 12 & 14 & 55 & 13 \\
\hline Crude fibre & 28 & - & 123 & 129 & 84 & 59 \\
\hline Ash & - & 7 & 68 & 64 & 70 & 61 \\
\hline Gross energy $(\mathrm{MJ} / \mathrm{kg})$ & $17 \cdot 1$ & $22 \cdot 0$ & $17 \cdot 6$ & $18 \cdot 6$ & $19 \cdot 3$ & $17 \cdot 6$ \\
\hline \multicolumn{7}{|l|}{ Essential amino acids } \\
\hline Threonine & $4 \cdot 5$ & 20 & 12 & 12 & 13 & 17 \\
\hline Valine & 6.9 & 26 & 15 & 14 & 17 & 20 \\
\hline Cystine & $5 \cdot 7$ & 29 & 13 & 12 & 14 & 15 \\
\hline Methionine & $2 \cdot 0$ & 11 & 4 & 5 & 6 & 5 \\
\hline Isoleucine & $5 \cdot 7$ & 26 & 11 & 10 & 14 & 19 \\
\hline Leucine & $11 \cdot 1$ & 49 & 19 & 19 & 25 & 30 \\
\hline Tyrosine & $5 \cdot 7$ & 26 & 9 & 9 & 11 & 12 \\
\hline Phenylalanine & $7 \cdot 2$ & 40 & 18 & 18 & 23 & 21 \\
\hline Histidine & $4 \cdot 7$ & 18 & 11 & 11 & 13 & 12 \\
\hline Lysine & $4 \cdot 7$ & 12 & 14 & 14 & 18 & 23 \\
\hline
\end{tabular}

L-threonine $0 \cdot 3$, L-tryptophan $0 \cdot 3$, mineral and vitamin premix 5 , bone meal 30 , solka floc $31 \cdot 5$, soya-bean oil 25 and wheat starch 156.4 . The wheat was of medium protein content and, in combination with the wheat gluten, supplied adequate quantities of all the amino acids except lysine, which was added to bring the basal level up to $5 \cdot 5 \mathrm{~g} / \mathrm{kg}$. Supplements of $\mathrm{L}$-threonine and L-tryptophan were added as a precaution. The four levels of lysine used to determine the pigs' response to standard lysine were in $625 \mathrm{mg}$ increments of $\mathrm{L}-\mathrm{lysine} / \mathrm{kg}$ and were obtained by the addition to the basal diet of L-lysine monohydrochloride (anhydrous, 98\% pure). The protein concentrates were incorporated into the diets to provide the same four levels of total lysine, as with standard lysine, at the expense of wheat starch. The free gossypol concentrations of cottonseed meals nos. 1 and 2 were 600 and $830 \mathrm{mg} / \mathrm{kg}$ respectively and the level in meal no. 3 was estimated at $500 \mathrm{mg} / \mathrm{kg}$. Ferrous sulphate was added to inactivate any effects the free gossypol may have in the diets (Tanksley \& Knabe, 1981). The mineral and vitamin premix contributed (mg/kg diet): iron 60 , zinc 100 , manganese 30 , copper 5 , iodine 2 , sodium chloride $2.8 \mathrm{~g}$, selenium $0 \cdot 15$, retinol equivalent $960 \mu \mathrm{g}$, cholecalciferol $12 \mu \mathrm{g}$, $\alpha$-tocopherol 20 , thiamin $1 \cdot 5$, riboflavin 3 , nicotinic acid 14 , pantothenic acid 10 , pyridoxine $2 \cdot 5$, cyanocobalamin $15 \mu \mathrm{g}$, pteroylmonoglutamic acid 2, choline 500 , ascorbic acid 10 , biotin $0 \cdot 1$.

The digestible energy contents of the protein concentrates and dietary components were estimated using results of previous determinations at this Institute. Dietary energy was maintained at $14 \cdot 1 \mathrm{MJ} / \mathrm{kg}$ digestible energy using wheat starch and soya-bean oil as nonprotein energy sources.

Animals and procedures. The twenty-one diets were arranged in a randomized block design. The pigs were blocked on 7-week weight, sex and position in the experimental facilities. There were six blocks, three containing males and three females, all of the Large White breed. The pigs were penned individually and water supplied by 'nipple' drinkers.

Dietary treatments were introduced when the pigs reached $20 \mathrm{~kg}$ live weight. The diets were offered at a daily rate of $1000 \mathrm{~g}$ at $20 \mathrm{~kg}$ live weight, with $100 \mathrm{~g}$ increments $/ 2.5 \mathrm{~kg}$ liveweight gain. The pigs were fed eight times daily, at intervals of $3 \mathrm{~h}$, with a solenoidcontrolled automatic frequency feeder to ensure the utilization of added free amino acids 
(Batterham \& Murison, 1981). The food was offered dry. Rations were adjusted after the weekly weighings of the pigs.

The pigs were slaughtered after reaching a minimum weight of $45 \mathrm{~kg}$ and hot eviscerated carcass weights were recorded. The carcasses were chilled overnight at $4^{\circ}$ then split. The left side of the carcass was stored at $-15^{\circ}$, then ground, mixed, sampled and freeze-dried before chemical analyses.

Pig response was assessed in terms of daily live-weight gain, FCE, killing-out proportion, carcass gain/d, FCE on a carcass basis, protein deposition/d, protein deposited/food intake and energy deposited/energy intake.

The following factors were used in the previously described calculations : 0.69 to convert initial live weight to estimated carcass weight (the factor of 0.69 for estimated carcass weight was previously determined with five male and five female piglets slaughtered at $20 \mathrm{~kg}$ live weight); 625 to convert nitrogen to protein (Agricultural Research Council, 1981); and 8.6 and 164 to calculate energy $(\mathrm{MJ} / \mathrm{kg})$ and protein $(\mathrm{g} / \mathrm{kg})$ in the carcasses at the commencement of the experiment for males and $9 \cdot 3$ and 152 for females respectively (these factors were determined on four males and four females previously slaughtered at $20 \mathrm{~kg}$ live weight).

Carcass gain per day, food conversion efficiency on a carcass basis, protein deposited per day and protein deposited/food intake were regressed against lysine dose level by the sloperatio assay technique of Finney (1964) for multiple assays (Table 2). The error degrees of freedom were reduced to ninety-seven as there were three missing plots (see Results section). Availability estimates and standard deviations were calculated.

The results for killing-out proportion and energy retention were regressed $v$. lysine for each protein concentrate. These analyses were conducted to determine if there was any effect of inclusion level of protein concentrate on these variables.

\section{Expt 2. Digestible energy concentration of the diets used in the slope-ratio assay}

Diets. The digestible energy contents of the five diets containing the highest dose level of standard lysine or test protein for the slope-ratio assay were determined.

Animals and procedures. The digestible energy in the diets was determined as reported by Batterham (1979). Four male pigs were used per diet and digestible energy was assessed using two $7 \mathrm{~d}$ total collections of faeces. Ferrous oxide $(10 \mathrm{~g} / \mathrm{kg})$ was used as a marker. Faeces were collected daily, stored at $-15^{\circ}$ until the end of the collection, thawed, mixed, sampled, freeze-dried and ground before chemical analysis.

\section{Expt 3. Ileal digestibility of amino acids}

The ileal digestibilities of amino acids in the four protein concentrates were determined. Five diets were used. The basal diet contained $(\mathrm{g} / \mathrm{kg})$ : wheat 976 , dicalcium phosphate 15 , salt 2 , mineral and vitamin premix 5 . In the four test diets, $300 \mathrm{~g}$ wheat $/ \mathrm{kg}$ was replaced by one of the four protein concentrates. Chromic oxide $(2 \mathrm{~g} / \mathrm{kg})$ was added to all diets for the estimation of ileal and faecal digestibility values.

Four male pigs of approximately $65 \mathrm{~kg}$ live weight were used. They had been fitted with ' $\mathrm{T}$ '-shaped cannulas about $300 \mathrm{~mm}$ anterior to the terminal ileum when $50 \mathrm{~kg}$ live weight. Each pig was given each diet in a completely randomized design. The pigs were given $0.75 \mathrm{~kg}$ of diet mixed with about 2 litres water at $12 \mathrm{~h}$ intervals. The diets were offered for $7 \mathrm{~d}$ and samples of faeces collected on the 6th day. On the 6th and 7 th days digesta samples of 70-100 $\mathrm{g}$ were collected from the cannulas at periods of $2,4,6$ and $8 \mathrm{~h}$ after feeding.

The treatment of samples and analytical methods used were as described by Taverner et al. (1983).

True lysine digestibility was calculated by subtracting a calculated amount for 
Table 2. Expt 1. Analysis of variance for slope-ratio analysis

\begin{tabular}{|c|c|c|c|}
\hline $\begin{array}{c}\text { Source of } \\
\text { variation }\end{array}$ & $\mathrm{df}$ & $\begin{array}{l}\text { Source of } \\
\text { variation }\end{array}$ & $\mathrm{d} \mathbf{f}$ \\
\hline Blocks & 5 & \multirow{2}{*}{\multicolumn{2}{|c|}{ Curvature }} \\
\hline Lysine (linear) & 1 & & \\
\hline Test 1 (linear) & 1 & Lysine & 2 \\
\hline Test 2 (linear) & 1 & Test 1 & 2 \\
\hline Test 3 (linear) & 1 & Test 2 & 2 \\
\hline Test 4 (linear) & 1 & Test 3 & 2 \\
\hline Blanks & 1 & Test 4 & 2 \\
\hline Intersection & & Error & 100 \\
\hline Test $1-$ lysine & 1 & Total & 125 \\
\hline Test 2 - lysine & 1 & & \\
\hline Test 3 - lysine & 1 & & \\
\hline Test 4 - lysine & 1 & & \\
\hline
\end{tabular}

Table 3. Composition ( $\mathrm{g} / \mathrm{kg}$, air-dry basis) of the diets for Expt 4

\begin{tabular}{|c|c|c|c|c|}
\hline Diet no.... & 1 & 2 & 3 & 4 \\
\hline \multicolumn{5}{|l|}{ Components } \\
\hline Wheat & 640 & 640 & 640 & 640 \\
\hline Cottonseed meal no. 2 & 260 & 260 & 260 & - \\
\hline Soya-bean meal & - & - & - & 220 \\
\hline L-Lysine monohydrochloride & 1.67 & $4 \cdot 36$ & $4 \cdot 36$ & - \\
\hline L-Threonine & - & - & $1 \cdot 0$ & - \\
\hline DL-Methionine & - & - & $0 \cdot 4$ & - \\
\hline L-Tryptophan & - & - & $0 \cdot 2$ & - \\
\hline Minerals and vitamins* & 5 & 5 & 5 & 5 \\
\hline Ferrous sulphate monohydrate & 0.7 & 0.7 & 0.7 & $\underline{-}$ \\
\hline Bone meal & 30 & 30 & 30 & 30 \\
\hline Solka floc & - & - & - & 29 \\
\hline Soya-bean oil & 50 & 50 & 50 & 18 \\
\hline Starch & $12 \cdot 63$ & $9 \cdot 94$ & $8 \cdot 34$ & 58 \\
\hline \multicolumn{5}{|l|}{ Composition } \\
\hline $\begin{array}{l}\text { Digestible energy (estimated) } \mathrm{MJ} / \mathrm{kg} \\
\text { Lysine: }\end{array}$ & $13 \cdot 9$ & $13 \cdot 9$ & 13.9 & $13 \cdot 9$ \\
\hline Total & 8 & $10 \cdot 1$ & $10 \cdot 1$ & 8 \\
\hline Available & 4.9 & 7 & 7 & 7 \\
\hline Crude protein (nitrogen $\times 6.25$ ) & 203 & 205 & 205 & 202 \\
\hline
\end{tabular}

* Composition as described for Expt 1, see p. 665 .

endogenous lysine from the total amount of ileal lysine and expressing the residual or undigested dietary lysine as a proportion of the total lysine intake. The value for endogenous lysine used was as given by Taverner et al. (1981).

Expt 4. Formulating diets to the slope-ratio assay values for available lysine Dietary components. The wheat, cottonseed no. 2 and soya-bean meal were as used in Expt 1.

Diets. Four diets were used (Table 3). The control diet (diet 1), was formulated from wheat, cottonseed meal no. 2 and L-lysine monohydrochloride to $8 \mathrm{~g}$ total lysine $/ \mathrm{kg}$. Diet 4 , a positive control, was formulated in a similar manner from wheat and soya-bean meal to $8 \mathrm{~g} / \mathrm{kg}$ total lysine. The available lysine content of diets 1 and 4 were 4.9 and $7 \mathrm{~g} / \mathrm{kg}$ 
Table 4. Expt 1. Live-weight gain, food conversion efficiency and killing-out proportion of pigs during the 20-45 kg growth phase when given the diets for the slope-ratio assay for lysine

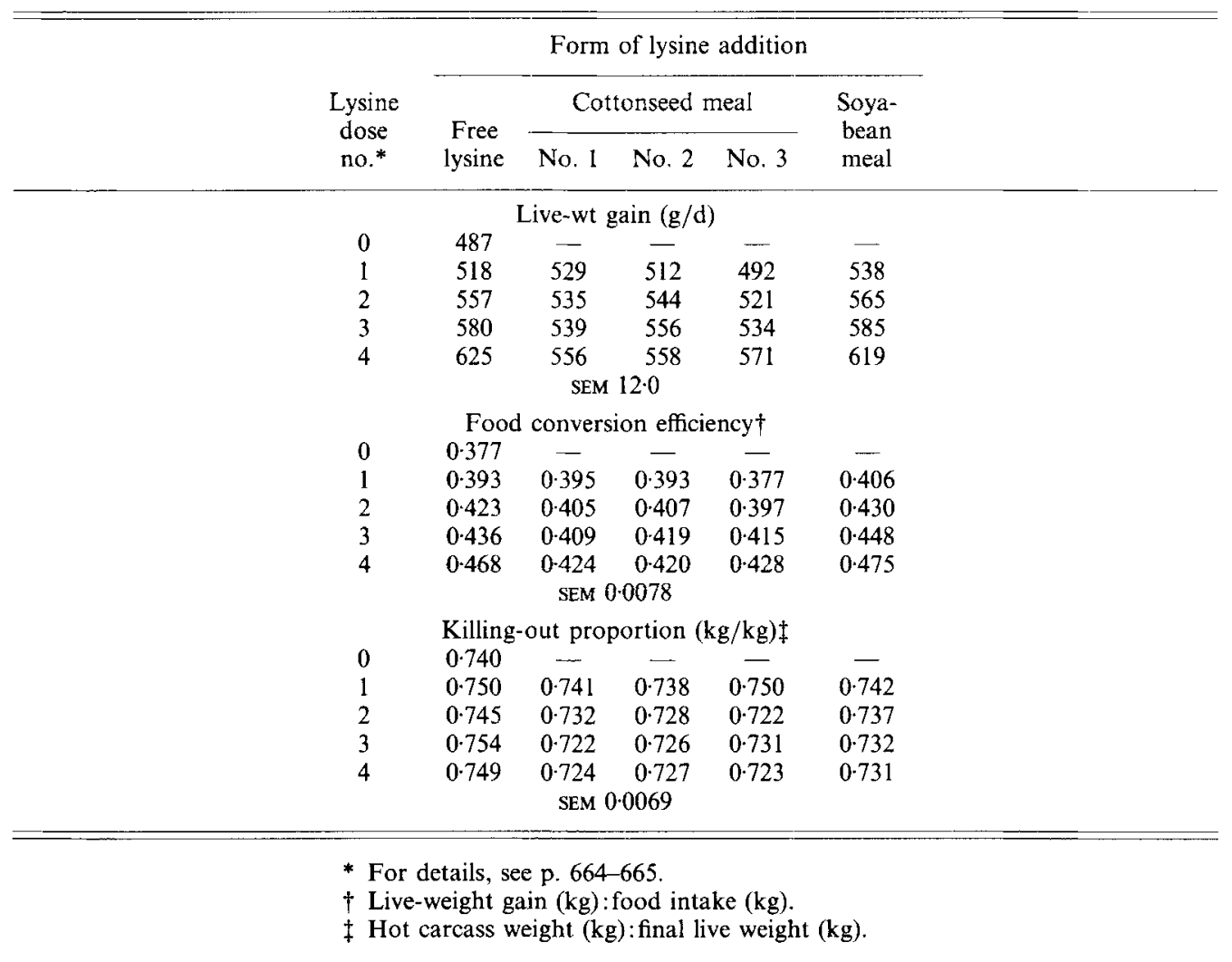

respectively. These values were based on the slope-ratio estimates of 0.3 and 0.9 for lysine availability in cottonseed meal no. 2 and soya-bean meal respectively and an estimate of 0.85 for lysine availability in the wheat base. This latter estimate was based on a value of 0.85 for the ileal digestibility of lysine in wheat (Standing Committee on Agriculture, 1987). Lysine was added to diet 2 to equalize the available lysine concentration with that of the diet containing soya-bean meal. In diet 3 , additional amino acids were added to maintain the amino acids : lysine ratio, as recommended by the Agricultural Research Council (1981). However, in this case the ratio was calculated on an available amino acid basis using the availability of lysine in cottonseed meal no. 2 as an estimator of availability for the other essential amino acids.

Assessment of performance. The four diets were allocated in a randomized block design with ten Large White male pigs allocated per diet. The pigs were blocked on 7-week weight, and position in the experimental facilities. Introduction of treatments, frequency of feeding and feeding rates were as for Expt 1 . To enable the retention of lysine in the pigs to be determined, the blood and viscera (washed free of internal contents) were collected at slaughter, and, together with the left-hand side, stored at $-15^{\circ}$, then ground, mixed, sampled and freeze-dried before chemical analyses. Energy stored as protein was calculated as carcass protein $(\mathrm{kg}) \times \mathbf{2 4 . 2}$ (Jordan \& Brown, 1970). Fat in the carcass was calculated as (carcass energy - protein energy):39.6 (Burlacu et al. 1973). The amino acid composition 
Table 5. Expt 1. Carcass gain, carcass food conversion efficiency (FCE) and protein deposited by pigs during the $20-45 \mathrm{~kg}$ growth phase when given the diets for the slope-ratio assay for lysine

\begin{tabular}{|c|c|c|c|c|c|}
\hline \multirow[b]{3}{*}{$\begin{array}{c}\text { Lysine } \\
\text { dose no.* }\end{array}$} & \multicolumn{5}{|c|}{ Form of lysine addition } \\
\hline & \multirow[b]{2}{*}{$\begin{array}{l}\text { Free } \\
\text { lysine }\end{array}$} & \multicolumn{3}{|c|}{ Cottonseed meal } & \multirow[b]{2}{*}{$\begin{array}{c}\text { Soya-bean } \\
\text { meal }\end{array}$} \\
\hline & & No. 1 & No. 2 & No. 3 & \\
\hline \multicolumn{6}{|c|}{ Carcass gain $(\mathrm{g} / \mathrm{d}) \dagger$} \\
\hline 0 & 379 & - & - & - & - \\
\hline 1 & 412 & 415 & 398 & 392 & 421 \\
\hline 2 & 438 & 409 & 412 & 388 & 437 \\
\hline 3 & 466 & 404 & 418 & 407 & 447 \\
\hline 4 & 495 & 416 & 421 & 427 & 472 \\
\hline \multicolumn{6}{|c|}{ SEM 10.5} \\
\hline \multicolumn{6}{|c|}{ FCE (carcass basis) $\ddagger$} \\
\hline 0 & 0.294 & - & - & - & - \\
\hline 1 & $0 \cdot 312$ & $0 \cdot 310$ & $0 \cdot 305$ & $0 \cdot 300$ & 0.318 \\
\hline 2 & 0.333 & 0.309 & 0.309 & $0 \cdot 296$ & 0.332 \\
\hline 3 & $0 \cdot 350$ & $0 \cdot 306$ & $0 \cdot 315$ & $0 \cdot 317$ & $0 \cdot 341$ \\
\hline 4 & $0 \cdot 370$ & $0 \cdot 318$ & 0.317 & $0 \cdot 321$ & $0 \cdot 362$ \\
\hline \multicolumn{6}{|c|}{ SEM 0.0069} \\
\hline \multicolumn{6}{|c|}{ Protein deposited $(\mathrm{g} / \mathrm{d}) \S$} \\
\hline 0 & $46 \cdot 7$ & - & - & - & - \\
\hline 1 & $51 \cdot 0$ & $52 \cdot 7$ & $51 \cdot 5$ & $52 \cdot 1$ & $52 \cdot 3$ \\
\hline 2 & $54 \cdot 4$ & $50 \cdot 8$ & $53 \cdot 3$ & $48 \cdot 5$ & $58 \cdot 6$ \\
\hline 3 & $65 \cdot 0$ & $51 \cdot 0$ & $55 \cdot 9$ & $50 \cdot 2$ & 63.7 \\
\hline 4 & $69 \cdot 2$ & $56 \cdot 4$ & $56 \cdot 2$ & $56 \cdot 5$ & $69 \cdot 6$ \\
\hline \multicolumn{6}{|c|}{ SEM 2.42} \\
\hline
\end{tabular}

* For details, see pp. 664-665.

$\dagger$ Hot carcass weight $(\mathrm{kg})-$ (initial live weight $(\mathrm{kg}) \times 0.69)$ :period $(\mathrm{d})$ on experiment.

$\$$ Hot carcass weight $(\mathrm{kg})-$ (initial live weight $(\mathrm{kg}) \times 0.69)$ : food intake $(\mathrm{kg})$.

$\S$ Protein in carcass $(\mathrm{kg})-(($ initial live-weight $(\mathrm{kg}) \times 0.69) \times 0.164$ (males) or $0.152($ females $))$ : period $(\mathrm{d})$ on experiment.

of composite samples of blood, viscera and carcass from the ten pigs for each diet was determined.

The results were analysed by analysis of variance and treatment means separated by least significant difference (LSD).

Chemical analyses. The techniques used were as reported by Batterham et al. (1979) except that gross energy was determined by adiabatic bomb calorimetry and amino acids in the carcass samples were determined by high-pressure liquid chromatography (Hughes \& Wilson, 1982). A two-buffer gradient-elution system with a Benson DX8.25 $8 \mu \mathrm{m}$ ionexchange column was used. Detection was by post-column derivatization with $o$ phthaldialdehyde-mercaptopropionic acid using u.v. absorption at $336 \mathrm{~nm}$. Tryptophan was determined by the method of Hugli \& Moore (1972).

\section{RESULTS}

Expt 1. Slope-ratio assay for lysine availability

Performance results of the pigs are presented in Tables 4-6. All pigs remained healthy throughout the experiment except one pig given diet 1 (blank) and two pigs given diet 14 (lowest inclusion level of cottonseed meal no. 3) which performed poorly and were withdrawn. 
Table 6. Expt 1. Protein deposited: food intake, and energy deposited: digestible energy intake by pigs during the $20-45 \mathrm{~kg}$ growth phase when given the diets for the slope-ratio assay for lysine

\begin{tabular}{|c|c|c|c|c|c|}
\hline \multirow{3}{*}{$\begin{array}{l}\text { Lysine } \\
\text { dose no.* }\end{array}$} & \multicolumn{5}{|c|}{ Form of lysine addition } \\
\hline & \multirow{2}{*}{$\begin{array}{l}\text { Free } \\
\text { lysine }\end{array}$} & \multicolumn{3}{|c|}{ Cottonseed meal } & \multirow{2}{*}{$\begin{array}{c}\text { Soya-bean } \\
\text { meal }\end{array}$} \\
\hline & & No. 1 & No. 2 & No. 3 & \\
\hline \multicolumn{6}{|c|}{ Protein deposited $(\mathrm{g})$ : food intake $(\mathrm{kg}) \dagger$} \\
\hline 0 & $36 \cdot 2$ & - & - & - & - \\
\hline 1 & $38 \cdot 7$ & $39 \cdot 4$ & $39 \cdot 5$ & $39 \cdot 9$ & $39 \cdot 5$ \\
\hline 2 & $41 \cdot 3$ & $38 \cdot 4$ & $39 \cdot 9$ & $37 \cdot 0$ & $44 \cdot 6$ \\
\hline 3 & $48 \cdot 9$ & 38.6 & $42 \cdot 2$ & $39 \cdot 1$ & $48 \cdot 7$ \\
\hline 4 & $51 \cdot 7$ & $43 \cdot 4$ & $42 \cdot 4$ & $42 \cdot 4$ & $53 \cdot 5$ \\
\hline \multicolumn{6}{|c|}{ SEM 1.86} \\
\hline \multicolumn{6}{|c|}{ Energy deposited $(\mathrm{MJ})$ : digestible energy intake $(\mathrm{MJ}) \ddagger$} \\
\hline 0 & $0 \cdot 424$ & - & - & - & - \\
\hline 1 & $0 \cdot 436$ & $0 \cdot 450$ & $0 \cdot 444$ & $0 \cdot 425$ & $0 \cdot 446$ \\
\hline 2 & $0 \cdot 445$ & $0 \cdot 444$ & 0.422 & $0 \cdot 410$ & $0 \cdot 441$ \\
\hline 3 & $0 \cdot 471$ & $0 \cdot 435$ & $0 \cdot 418$ & 0.423 & 0.418 \\
\hline 4 & $0 \cdot 457$ & $0 \cdot 422$ & 0.412 & 0.418 & 0.431 \\
\hline \multicolumn{6}{|c|}{ SEM 0.0104} \\
\hline
\end{tabular}

* For details, see pp. 664665 .

$\dagger$ Crude protein (nitrogen $\times 6.25)$ in carcass $(\mathrm{g})-(($ initial live weight $(\mathrm{kg}) \times 0.69) \times 0.164$ (males) or 0.152 (females)) : food intake $(\mathrm{kg})$. $(\mathrm{MJ})$.

$\ddagger$ Energy in carcass $(\mathrm{MJ})-(($ initial live weight $\times 0.69) \times 8.6$ (males) or 9.3 (females)): digestible energy intake

Table 7. Expt 1. Availability of lysine (proportion of total) in the protein concentrates as assessed by the slope-ratio analysis

(Mean values and standard deviations)

\begin{tabular}{|c|c|c|c|c|c|c|c|c|}
\hline \multirow[b]{2}{*}{ Protein concentrate } & \multicolumn{2}{|c|}{$\begin{array}{c}\text { Daily } \\
\text { carcass gain }\end{array}$} & \multicolumn{2}{|c|}{$\begin{array}{c}\text { Carcass } \\
\text { gain : food intake }\end{array}$} & \multicolumn{2}{|c|}{$\begin{array}{c}\text { Protein } \\
\text { deposited/d }\end{array}$} & \multicolumn{2}{|c|}{$\begin{array}{l}\text { Protein } \\
\text { deposited : food } \\
\text { intake }\end{array}$} \\
\hline & Mean & SD & Mean & SD & Mean & $\mathrm{SD}$ & Mean & $\mathrm{SD}$ \\
\hline \multicolumn{9}{|l|}{ Cottonseed meal: } \\
\hline No. 1 & 0.27 & 0.09 & 0.27 & $0 \cdot 08$ & 0.38 & $0 \cdot 10$ & $0 \cdot 39$ & $0 \cdot 11$ \\
\hline No. 2 & $0 \cdot 34$ & 0.09 & $0 \cdot 30$ & $0-08$ & 0.49 & $0 \cdot 10$ & 0.48 & 0.11 \\
\hline No. 3 & 0.26 & 0.09 & 0.29 & 0.08 & 0.33 & $0 \cdot 10$ & 0.35 & $0 \cdot 11$ \\
\hline Soya-bean meal & 0.81 & $0 \cdot 10$ & $0 \cdot 90$ & $0-09$ & $1 \cdot 05$ & $0 \cdot 12$ & $1 \cdot 12$ & $0 \cdot 13$ \\
\hline
\end{tabular}

The level of inclusion of protein concentrate depressed the killing-out proportions of pigs given the diets containing cottonseed meal $(P<0 \cdot 05)$ (Table 4$)$. The proportion of energy retained in the carcasses increased for those pigs given the diets containing free lysine, and decreased for those pigs given the diets containing cottonseed meals nos. 1 and $2(P<0.05$; Table 6).

Using FCE on a carcass basis as the criterion of response, lysine availability was low in the three cottonseed meals $(0 \cdot 27-0.30$; Table 7$)$ and high in the soya-bean meal $(0 \cdot 90)$.

When the estimates of availability were assessed on a protein deposited/d or protein deposited : food intake basis the values were higher than the estimates based on carcass data 
Table 8. Expt 3. The apparent ileal digestibilities of amino acids, nitrogen and dry matter in the diets*

\begin{tabular}{|c|c|c|c|c|c|c|}
\hline \multirow[b]{2}{*}{ Diets... } & \multirow[b]{2}{*}{ Wheat } & \multicolumn{3}{|c|}{ Cottonseed } & \multirow{2}{*}{$\begin{array}{c}\text { Soya } \\
\text { bean }\end{array}$} & \multirow[b]{2}{*}{ SEM } \\
\hline & & No. 1 & No. 2 & No. 3 & & \\
\hline \multicolumn{7}{|l|}{ Amino acids } \\
\hline Lysine & $0.80^{\mathrm{b}}$ & $0 \cdot 64^{d}$ & $0.71^{\mathrm{c}}$ & $0.73^{c}$ & $0.87^{a}$ & 0.014 \\
\hline Histidine & $0.86^{a}$ & $0.78^{i}$ & $0 \cdot 83^{b}$ & $0 \cdot 86^{\mathrm{a}}$ & $0.87^{a}$ & $0 \cdot 006$ \\
\hline Arginine & $0.85^{\circ}$ & $0.85^{\mathrm{c}}$ & $0 \cdot 88^{b}$ & $0.91^{\mathrm{a}}$ & $0.89^{a b}$ & 0.007 \\
\hline Aspartic acid & $0.78^{\mathrm{n}}$ & $0 \cdot 70^{\mathrm{c}}$ & $0.77^{\mathrm{b}}$ & $0 \cdot 80^{\mathrm{ab}}$ & $0 \cdot 82^{\mathrm{a}}$ & 0.010 \\
\hline Threonine & $0.72^{b}$ & $0.59^{c}$ & $0.68^{c}$ & $0.73^{\mathrm{ab}}$ & $0.76^{\mathrm{a}}$ & 0.013 \\
\hline Serine & $0 \cdot 81^{a}$ & $0.71^{\mathrm{c}}$ & $0 \cdot 76^{\mathrm{b}}$ & $0 \cdot 80^{\mathrm{a}}$ & $0 \cdot 82^{a}$ & 0.008 \\
\hline Glutamic acid & $0.93^{a}$ & $0.84^{d}$ & $0.88^{\mathrm{c}}$ & $0.90^{\mathrm{b}}$ & $0.89^{\mathrm{Dc}}$ & 0.004 \\
\hline Proline & $0.92^{\mathrm{a}}$ & $0 \cdot 74^{\mathrm{d}}$ & $0 \cdot 80^{\mathrm{c}}$ & $0.80^{\circ}$ & $0 \cdot 86^{\mathrm{b}}$ & 0.012 \\
\hline Glycine & $0.62^{\mathrm{b}}$ & $0.63^{b}$ & $0 \cdot 70^{\mathrm{a}}$ & $0.74^{\mathrm{a}}$ & $0 \cdot 74^{a}$ & 0.019 \\
\hline Alanine & $0.78^{\mathrm{a}}$ & $0.68^{c}$ & $0 \cdot 74^{b}$ & $0.78^{a}$ & $0.81^{\text {H }}$ & 0.010 \\
\hline Valine & $0.82^{\mathrm{a}}$ & $0.72^{\circ}$ & $0.78^{\mathrm{b}}$ & $0 \cdot 81^{\mathrm{a}}$ & $0.83^{a}$ & 0.008 \\
\hline Methionine & $0.90^{\mathrm{a}}$ & $0 \cdot 79^{\circ}$ & $0 \cdot 84^{\mathrm{b}}$ & $0.87^{\mathrm{ab}}$ & $0 \cdot 90^{\mathrm{a}}$ & 0.011 \\
\hline Isoleucine & $0.85^{a}$ & $0 \cdot 72^{\mathrm{d}}$ & $0.78^{\circ}$ & $0.81^{\mathrm{b}}$ & $0 \cdot 86^{a}$ & 0.007 \\
\hline Leucine & $0 \cdot 86^{\mathrm{a}}$ & $0.73^{d}$ & $0.79^{\circ}$ & $0.82^{\mathrm{b}}$ & $0 \cdot 86^{\mathrm{a}}$ & 0.007 \\
\hline Tyrosine & $0 \cdot 84^{a}$ & $0.74^{d}$ & $0.78^{c}$ & $0.81^{b}$ & $0 \cdot 83^{\text {ab }}$ & 0.008 \\
\hline Phenylalanine & $0.81^{\mathrm{b}}$ & $0.75^{\mathrm{c}}$ & $0.81^{\mathrm{b}}$ & $0 \cdot 87^{a}$ & $0 \cdot 83^{b}$ & 0.011 \\
\hline $\mathrm{N}$ & $0.82^{\mathrm{ab}}$ & $0.75^{\mathrm{c}}$ & $0.77^{\mathrm{c}}$ & $0 \cdot 80^{\mathrm{b}}$ & $0.83^{a}$ & 0.007 \\
\hline Dry matter & $0.79^{a}$ & $0.63^{c}$ & $0 \cdot 68^{\mathrm{b}}$ & $0.71^{\mathrm{b}}$ & $0 \cdot 70^{\mathrm{b}}$ & 0.011 \\
\hline
\end{tabular}

a, b, e, d Within each line, mean values with different superscript letters were significantly different $(P<0 \cdot 05)$.

* For details, see Table 1 .

for all meals. In the case of soya-bean meal, the estimates of availability were greater than $1 \cdot 0$.

Expt 2. Digestible energy concentration of the diets used in the slope-ratio assay The digestible energy concentration in the diets containing the highest quantity of standard or test lysine were (MJ/kg; mean with SEM, air-dry basis): standard lysine, 14.6 (SEM 0.12); cottonseed meal no. 1 , 14.0 (SEM 0.05); no. 2, 14.3 (SEM 0.11); no. 3, 15.0 (SEM 0.06); soyabean meal, 14.9 (SEM $0 \cdot 15$ ).

\section{Expt 3. Ileal digestibility of amino acids}

The ileal digestibilities of amino acids, $\mathrm{N}$ and dry matter in the diets are given in Table 8 . Those for the individual protein meals were calculated by apportioning the differences between the basal wheat diet and the test diets to the nutrients added by the protein meals. These values are given in Table 9 . The apparent ileal digestibilities of most amino acids and of $\mathrm{N}$ in the three cottonseed meals were less $(P<0.05)$ than in the soya-bean meal. Furthermore there were differences $(P<0.05)$ in ileal digestibility among the cottonseed meal samples; for dry matter and most amino acids, ileal digestibilities increased $(P<0.05)$ from cottonseed meal no. 1 , to no. 2 and then to no. 3 . The true ileal digestibility of lysine in the protein meals was similar to the apparent ileal digestibility and differed significantly among the cottonseed meals $(0.58,0.68$ and 0.72 for nos. 1,2 and 3 respectively), and that in soya-bean meal was significantly higher $(0.89 ; P<0.01)$ than for the cottonseed meals.

Expt 4. Formulating diets to the slope-ratio assay values for available lysine Pigs given diet 1 (cottonseed meal no. 2) grew more slowly and had a lower FCE than pigs given diet 4 (soya-bean meal; $P<0.05$; Table 10). The addition of lysine in diet 2 to equalize 
Table 9. Expt 3. Apparent ileal digestibilities of amino acids, nitrogen and dry matter in the protein concentrates

\begin{tabular}{|c|c|c|c|c|c|}
\hline \multirow[b]{2}{*}{ Protein concentrate... } & \multicolumn{3}{|c|}{ Cottonseed meal } & \multirow{2}{*}{$\begin{array}{l}\text { Soya } \\
\text { bean }\end{array}$} & \multirow[b]{2}{*}{ SEM } \\
\hline & No. 1 & No. 2 & No. 3 & & \\
\hline \multicolumn{6}{|l|}{ Amino acids } \\
\hline Lysine & $0.56^{\circ}$ & $0.67^{b}$ & $0.71^{\mathrm{b}}$ & $0.88^{\mathrm{a}}$ & 0.021 \\
\hline Histidine & $0.72^{c}$ & $0.80^{\mathrm{b}}$ & $0.86^{\mathrm{a}}$ & $0 \cdot 87^{\mathrm{a}}$ & 0.008 \\
\hline Arginine & $0 \cdot 85^{\mathrm{c}}$ & $0.89^{b}$ & $0 \cdot 92^{\mathrm{a}}$ & $0.91^{\mathrm{a}}$ & $0 \cdot 005$ \\
\hline Aspartic acid & $0.67^{c}$ & $0.77^{\mathrm{b}}$ & $0.80^{\mathrm{ab}}$ & $0.83^{a}$ & $0 \cdot 014$ \\
\hline Threonine & $0.51^{c}$ & $0.64^{\mathrm{b}}$ & $0.73^{a}$ & $0.77^{\mathrm{a}}$ & 0.020 \\
\hline Serine & $0 \cdot 64^{\mathrm{c}}$ & $0.73^{b}$ & $0.80^{\mathrm{a}}$ & $0.82^{\mathrm{a}}$ & 0.015 \\
\hline Glutamic acid & $0.76^{\mathrm{c}}$ & $0.85^{\mathrm{b}}$ & $0.88^{a}$ & $0 \cdot 86^{\mathrm{ab}}$ & 0.008 \\
\hline Proline & $0.56^{\mathrm{ah}}$ & $0.48^{b}$ & $0.52^{\mathrm{b}}$ & $0.69^{\mathrm{a}}$ & $0-046$ \\
\hline Glycine & $0 \cdot 64^{\mathrm{b}}$ & $0 \cdot 75^{\mathrm{a}}$ & $0.81^{\mathrm{a}}$ & $0.81^{\mathrm{a}}$ & 0.024 \\
\hline Alanine & $0.61^{\mathrm{e}}$ & $0.72^{b}$ & $0.79^{a}$ & $0.82^{\mathrm{a}}$ & $0 \cdot 018$ \\
\hline Valine & $0 \cdot 66^{c}$ & $0.76^{b}$ & $0.81^{\mathrm{a}}$ & $0.84^{\mathrm{a}}$ & 0.013 \\
\hline Methionine & $0.72^{\mathrm{c}}$ & $0.80^{\mathrm{b}}$ & $0.85^{\text {ab }}$ & $0.90^{\mathrm{a}}$ & 0.019 \\
\hline Isoleucine & $0.63^{d}$ & $0.73^{c}$ & $0.79^{\mathrm{b}}$ & $0 \cdot 86^{\mathrm{a}}$ & 0.013 \\
\hline Leucine & $0.63^{d}$ & $0.74^{c}$ & $0 \cdot 80^{\mathrm{b}}$ & $0.85^{\mathrm{a}}$ & 0.012 \\
\hline Tyrosine & $0 \cdot 66^{c}$ & $0.74^{\mathrm{b}}$ & $0.79^{\mathbf{a}}$ & $0.82^{a}$ & $0-015$ \\
\hline Phenylalanine & $0.72^{\mathrm{c}}$ & $0.81^{\mathrm{b}}$ & $0.89^{a}$ & $0.83^{b}$ & 0.015 \\
\hline $\mathbf{N}$ & $0.71^{\mathrm{c}}$ & $0.73^{c}$ & $0.78^{\mathrm{b}}$ & $0 \cdot 83^{a}$ & $0 \cdot 013$ \\
\hline Dry matter & $0 \cdot 26^{\mathrm{b}}$ & $0.41^{a}$ & $0.52^{\mathrm{a}}$ & $0 \cdot 49^{\mathrm{a}}$ & 0.036 \\
\hline
\end{tabular}

a,b,c,d Within each line, mean values with different superscript letters were significantly different $(P<0.05)$.

Table 10. Expt 4. Effect of formulating diets on a total or available lysine basis on the growth performance of pigs given diets containing cottonseed meal no. 2 (Cot) or soya-bean meal $(\text { Soya })^{*}$

\begin{tabular}{|c|c|c|c|c|c|c|}
\hline Diet no.... & $\begin{array}{c}1 \\
\mathrm{Cot}\end{array}$ & $\begin{array}{c}2 \\
\text { Cot }+ \text { lysine }\end{array}$ & $\begin{array}{c}3 \\
\text { Cot }+ \text { lysine } \\
+\mathrm{AA}\end{array}$ & $\begin{array}{c}4 \\
\text { Soya }\end{array}$ & \multicolumn{2}{|c|}{$\begin{array}{l}\text { Statistical } \\
\text { significance }\end{array}$} \\
\hline $\begin{array}{l}\text { Total } \\
\text { Available }\end{array}$ & $\begin{array}{l}8 \\
4 \cdot 9\end{array}$ & $\begin{array}{c}10 \cdot 1 \\
7\end{array}$ & $\begin{array}{l}10 \cdot 1 \\
7\end{array}$ & $\begin{array}{l}8 \\
7\end{array}$ & $P=0.05$ & SEM \\
\hline Gain $(\mathrm{g} / \mathrm{d})$ & 541 & 607 & 610 & 631 & 22 & $7 \cdot 5$ \\
\hline Food conversion efficiency & 0.424 & 0.470 & 0.479 & 0.492 & 0.017 & 0.0057 \\
\hline Empty-body-wt:live wt $(\mathrm{kg} / \mathrm{kg})$ & 0.890 & 0.894 & 0.899 & 0.901 & NS & 0.0038 \\
\hline Gain (g/d) (empty-body-wt basis) & 476 & 539 & 546 & 566 & 22 & $7 \cdot 5$ \\
\hline $\begin{array}{l}\text { Food conversion efficiency } \\
\text { (empty-body-wt basis) }\end{array}$ & $0 \cdot 372$ & $0 \cdot 417$ & 0.429 & 0.441 & 0.017 & $0 \cdot 0056$ \\
\hline Backfat $\left(\mathrm{P}_{2} ; \mathrm{mm}\right)$ & 12 & 12 & 12 & 12 & NS & $0 \cdot 6$ \\
\hline
\end{tabular}

AA, amino acids; LSD, least significant difference; NS, not significant.

* For details, see Table 3 .

the available lysine content with that in diet 4 significantly $(P<0.05)$ increased growth rate and FCE but not to that achieved by pigs given diet 4 . The addition of methionine, threonine and tryptophan in diet 3 had small but non-significant $(P>0.05)$ effects on growth rates and FCE and there were no significant $(P>0.05)$ differences between pigs given diets 3 and 4 .

There were no differences $(P>0.05)$ in fat deposition per day nor energy de- 
Table 11. Expt 4. Effect of formulating diets on a total or available lysine basis on the composition, deposition rates and efficiency of retention of nutrients in pigs given diets containing cottonseed meal no. 2 (Cot) or soya-bean meal (Soya)*

\begin{tabular}{|c|c|c|c|c|c|c|}
\hline Diet no.... & $\begin{array}{c}1 \\
\text { Cot }\end{array}$ & $\begin{array}{c}2 \\
\text { Cot }+ \text { lysine }\end{array}$ & $\begin{array}{c}3 \\
\text { Cot }+ \text { lysine } \\
+\mathrm{AA}\end{array}$ & $\begin{array}{c}4 \\
\text { Soya }\end{array}$ & \multicolumn{2}{|c|}{$\begin{array}{c}\text { Statistical } \\
\text { significance }\end{array}$} \\
\hline Total & 8 & $10 \cdot 1$ & $10 \cdot 1$ & 8 & LSD & \\
\hline Available & 4.9 & 7 & 7 & 7 & $P=0.05$ & SEM \\
\hline \multicolumn{7}{|l|}{ Composition (empty-body basis) } \\
\hline Protein $(\mathrm{kg} / \mathrm{kg})$ & 0.162 & 0.168 & $0 \cdot 170$ & 0.171 & 0.005 & 0.0016 \\
\hline Fat $(\mathrm{kg} / \mathrm{kg})$ & $0 \cdot 199$ & 0.177 & 0.178 & $0 \cdot 166$ & 0.010 & 0.0035 \\
\hline Energy $(\mathbf{M J} / \mathrm{kg})$ & 11.8 & $11 \cdot 1$ & $11 \cdot 2$ & 10.7 & 0.4 & $0 \cdot 13$ \\
\hline \multicolumn{7}{|l|}{ Deposition rates } \\
\hline Protein $(\mathrm{g} / \mathrm{d})$ & 74 & 90 & 94 & 99 & $5 \cdot 3$ & 1.8 \\
\hline Fat & 135 & 129 & 133 & 124 & NS & 3.9 \\
\hline \multicolumn{7}{|l|}{ Retention } \\
\hline Energy retained: $D E$ intake $(\mathrm{MJ} / \mathrm{MJ})$ & 0.43 & $0 \cdot 43$ & 0.46 & 0.44 & NS & 0.008 \\
\hline Lysine retained: total lysine intake & 0.44 & 0.40 & 0.44 & 0.56 & 0.027 & $0-009$ \\
\hline $\begin{array}{l}\text { Lysine retained : ileal digestible } \\
\text { lysine intake }\end{array}$ & 0.56 & 0.48 & 0.53 & 0.63 & 0.032 & 0.011 \\
\hline Lysine retained : available lysine intake & 0.72 & $0 \cdot 57$ & 0.64 & 0.64 & 0.038 & 0.013 \\
\hline
\end{tabular}

AA, amino acids; LSD, least significant difference; NS, not significant.

* For details, see Table 3.

posited: digestible energy intake for pigs given the four diets (Table 11). Crude protein deposited per day was significantly greater $(P<0.05)$ in pigs given diet 4 relative to pigs given diet 1 . The combined addition of lysine and the amino acid supplement to diet 3 overcame this difference.

iysine concentration in the empty bodies of the pigs averaged $5.9 \mathrm{~g} / 16 \mathrm{~g} \mathrm{~N}$ and appeared unaffected by the degree of lysine deficiency (Table 12). Lysine deposited : total lysine intake was higher in pigs given diet 4 relative to the other three diets (Table $11 ; P<0.05$ ). Lysine deposited:ileal digestible lysine intake was also greater in pigs given diet 4 relative to the other three diets $(P<0.05)$. Lysine deposited : available lysine intake was highest in pigs given diet 1 , least in pigs given diet 2 , and similar in pigs given diets 3 and $4(P<0.05)$.

\section{DISCUSSION}

\section{Determining lysine availability}

The estimate of availability of 0.90 for soya-bean meal, based on FCE on a carcass basis, is similar to previous determinations $(0.84-0.98$; Batterham et al. 1979, 1984). The values for cottonseed meal of $0.27-0.30$ availability are slightly lower than previous estimates $(0.39-0.43$; Batterham et al. 1979, 1984). However, considering the standard deviations of the determinations were $0.08-0.09$, the results indicate that lysine availability is uniformly low in cottonseed meals and high in soya-bean meals.

The higher estimates for availability when the results were expressed on a protein deposition basis are difficult to explain (Table 7). Theoretically, there should be no difference in the estimates. When energy intake is controlled and lysine limiting, growth response and protein deposition should be related to lysine intake. Increasing the lysine level increases the lysine: energy ratio which should increase lean deposition and growth rate. In a previous assay (Batterham et al. 1986) there was also little agreement between 
Table 12. Expt 4. Amino acid composition ( $\mathrm{g} / 16 \mathrm{~g}$ nitrogen) of the carcasses of pigs slaughtered at $20 \mathrm{~kg}$ and at $45 \mathrm{~kg}$ when given diets nos. $1-4^{*}$

\begin{tabular}{|c|c|c|c|c|c|}
\hline \multirow{2}{*}{$\begin{array}{l}\text { Wt of pigs }(\mathrm{kg}) \ldots \\
\text { Diet no.... }\end{array}$} & \multirow[t]{2}{*}{20} & \multicolumn{4}{|c|}{45} \\
\hline & & 1 & 2 & 3 & 4 \\
\hline Aspartic acid & $7 \cdot 42$ & $7 \cdot 44$ & 7.07 & $7 \cdot 23$ & $7 \cdot 62$ \\
\hline Threonine & $3 \cdot 40$ & 3.63 & $3 \cdot 46$ & $3 \cdot 55$ & $3 \cdot 32$ \\
\hline Serine & 3.72 & 3.71 & 3.55 & $3 \cdot 79$ & 3.69 \\
\hline Glutamic acid & 11.75 & $11 \cdot 54$ & $11 \cdot 10$ & $12 \cdot 06$ & $11 \cdot 75$ \\
\hline Glycine & $7 \cdot 66$ & $8 \cdot 22$ & 7.96 & $8 \cdot 20$ & $8 \cdot 20$ \\
\hline Alanine + cystine $\dagger$ & 6.93 & 7.06 & 6.79 & $7 \cdot 05$ & $7 \cdot 15$ \\
\hline Valine & $3 \cdot 58$ & 3.66 & 3.49 & $3 \cdot 66$ & $3 \cdot 65$ \\
\hline Methionine & 1.71 & 1.86 & $1 \cdot 70$ & 1.74 & $1-69$ \\
\hline Isoleucine & $2 \cdot 71$ & 2.68 & 2.58 & $2 \cdot 62$ & 2.72 \\
\hline Leucine & $6 \cdot 35$ & $6 \cdot 30$ & 6.09 & $6 \cdot 16$ & $6 \cdot 20$ \\
\hline Tyrosine & $2 \cdot 43$ & 2.59 & $2 \cdot 50$ & $2 \cdot 51$ & $2 \cdot 43$ \\
\hline Phenylalanine & 3.04 & $3 \cdot 38$ & $3 \cdot 20$ & $3 \cdot 24$ & $3 \cdot 14$ \\
\hline Histidine & $3 \cdot 38$ & $3 \cdot 35$ & $3 \cdot 10$ & $3 \cdot 58$ & $3 \cdot 73$ \\
\hline Lysine & $5 \cdot 71$ & 6.09 & $5 \cdot 72$ & 6.03 & $5 \cdot 84$ \\
\hline Ammonia & $2 \cdot 21$ & $2 \cdot 49$ & $2 \cdot 44$ & $2 \cdot 00$ & $2 \cdot 20$ \\
\hline Arginine & 605 & 6.58 & 5.49 & $6 \cdot 13$ & 6.08 \\
\hline Tryptophan & 0.89 & 0.93 & $0 \cdot 95$ & 0.90 & 0.92 \\
\hline Proline & $6 \cdot 05$ & 6.05 & 6.05 & $6 \cdot 05$ & 6.05 \\
\hline Hydroxyproline $\$$ & $2 \cdot 69$ & $2 \cdot 69$ & 2.69 & 2.69 & 2.69 \\
\hline Proportion of nitrogen recovered & $0 \cdot 88$ & 0.90 & $0 \cdot 86$ & 0.89 & 0.89 \\
\hline
\end{tabular}

* For details, see Table 3.

$\uparrow$ Incomplete separation of alanine and cystine prevented quantification of these amino acids.

$\ddagger$ Not determined, values based on Campbell et al. (1988).

availability estimates based on a carcass or protein deposition basis. In that assay the standard deviations were higher with the protein values and this may have contributed to the differences in estimates. In the current assay, the standard deviations for protein deposited: food intake $(0 \cdot 11-0 \cdot 13)$ are also higher than those for FCE on a carcass basis $(0 \cdot 08-0 \cdot 09)$. However, this should not result in a uniform increase in estimates for all meals. The availability estimates based on FCE on a carcass basis appear more realistic than those based on protein deposition, as the value for soya-bean meal with the latter is greater than $1 \cdot 0(1 \cdot 12)$. This assessment is also supported by the results of Expt 4 where diets formulated to similar available lysine values, that were based on FCE on a carcass basis, gave similar pig performance.

The range in digestible energy in the diets containing the highest concentrations of lysine from the standard lysine and test proteins in Expt 2 was small and should not have influenced the estimates of availability. The increase in energy retained by the pigs given the diets containing the standard lysine is presumably a reflection of $(a)$ savings in maintenance energy as a result of the increased growth rate and $(b)$ a decrease in the amount of surplus amino acids to be catabolized as a result of an improvement in the amino acid balance of the diets with increasing lysine supplementation. The lower energy retention of pigs given the cottonseed and soya-bean meals may reflect an increase in energy costs associated with deaminating surplus amino acids contributed by the protein concentrates.

The estimates for lysine availability in cottonseed meal $(0 \cdot 27-0 \cdot 30)$ for grower pigs are considerably lower than values of 0.69-0.75 for weaner pigs reported by Leibholz (1986). It is unlikely that these differences are due to differences in samples of meal or tolerances of pigs, but may reflect differences in methodology. In the assay conducted by Leibholz 
(1986), weight gain per day was used as the variable for assessing availability and the values were not derived from the traditional slope-ratio assay analysis of Finney (1964) as, in general, the regression lines fitted did not pass through a common intercept. Using weight gain per day overestimated availability by 0.19 units in an assay with cottonseed meal (Batterham et al. 1979). This occurred as live weight was influenced by increasing gut fill in pigs given cottonseed meal at the expense of highly digestible wheat starch. Analysing the results by regressing live-weight gain $v$. lysine intake can also give higher values (up to 0.26 units) for availability compared with regressing the results against dose level (Batterham et al. 1986). Thus, both of these factors may have contributed to the differences in assay values.

The low availabilities of lysine $(0 \cdot 27-0 \cdot 30)$ in the cottonseed meals are unlikely to be due to the presence of antinutritional factors. Cottonseed meal contains gossypol, which, in excess, is toxic to pigs. However, the pigs can tolerate $100 \mathrm{mg}$ free gossypol $/ \mathrm{kg}$ without effect, or up to $500 \mathrm{mg} / \mathrm{kg}$ if iron is used to bind the free gossypol (Tanksley \& Knabe, 1981). In the slope-ratio assays, the maximum free gossypol concentration was $148 \mathrm{mg} / \mathrm{kg}$. Since ferrous sulphate was added to the diets, it is unlikely that gossypol would have had any effect. Cottonseed meal also contains cyclopropenoid fatty acids, which increase the ratio of saturated: unsaturated fatty acids by inhibiting the normal desaturation process during lipid synthesis in the liver (Allen et al. 1967). However, the cyclopropenoid fatty acids have not been shown to affect growth, and in any case, would be in very low levels in solvent-extracted meals. Cottonseed meal contains no other antinutritional factors known to interfere with pig performance (Tanksley \& Knabe, 1981).

The low availabilities of lysine in cottonseed meal are more likely due to the severe processing conditions used to render the free gossypol inactive. Both heat and moisture are used to bind gossypol, which is reduced to approximately 0.06 availability. As both heat and moisture also depress lysine availability, it is not surprising that lysine availability is reduced to $0 \cdot 27-0 \cdot 30$ in cottonseed meal.

\section{Ileal digestibility of lysine}

The ileal digestibility values for lysine in the cottonseed and soya-bean meals (Expt 3 ) are similar to previous determinations and to reports in the literature (Taverner et al. 1983; Leibholz, 1986; Sauer \& Ozimek, 1986). The average (0.65) and the range in values $(0.56-0.71)$ of apparent digestibility of lysine in cottonseed meal in the current experiment were similar to that reported by Sauer \& Ozimek (1986) in a collation of published values for cottonseed meals (mean $0 \cdot 62$, range $0 \cdot 53-0 \cdot 70$ ).

Whereas lysine was considerably less digestible than $\mathrm{N}$ in cottonseed meal, the situation appeared to be reversed in soya-bean meal in which lysine was more digestible than N. It is known that, because of its free $\epsilon$-amino group, lysine is primarily affected when heat is applied to cottonseed protein in the presence of gossypol (Baligna \& Lyman, 1957).

\section{Formulating diets on an available lysine basis}

The similar performance of pigs in Expt 4, when given diets formulated on an available lysine basis compared with the large differences when the diets were formulated on a total lysine basis (1) confirms that these values are applicable and (2) illustrates the need to formulate diets on an available rather than total lysine basis. The small but mostly nonsignificant responses of pigs to the supplement of amino acids (diet 3) suggests that one or more of these amino acids was also limiting in the diet containing cottonseed meal no. 2. If this is so, then it seems possible that the availability of one or more of these amino acids in cottonseed was reduced during processing and it is necessary to take this into account when formulating diets. Whilst the availability of lysine can be used as an estimator of the 
availability of the other essential amino acids, there is a need to determine separately the availability of each of the essential amino acids in cottonseed meal to define more accurately their status.

The similar quantity of lysine in the crude protein $(\mathrm{g} / 16 \mathrm{~g} \mathrm{~N})$ of pigs given the four diets indicates that the degree of dietary lysine deficiency (within the range examined) had no apparent effect on the amino acid composition of the protein. However, pigs given the lysine-deficient diet (diet 1) were more efficient in their utilization of lysine than pigs given diets containing more adequate quantities of lysine (diets 3 and 4). Overall retention of available lysine by pigs given diets 3 and 4 was only 0.64 . As the slope-ratio assay value of availability has already allowed for the endogenous cost of digestion, the 0.36 proportion of available lysine not retained possibly reflects the metabolic cost of protein turnover.

\section{Comparison of lysine availability and ileal digestibility}

The results show that, for soya-bean meal, there is close agreement between values for both techniques. Thus, for 'prepress' solvent-extracted soya-bean meal, reduced digestibility at the terminal ileum appears the major cause of availability being less than $1 \cdot 0$. As a consequence, the ileal digestibility of lysine can be used to estimate lysine availability for high-quality soya-bean meal.

For cottonseed meal, ileal digestibility overestimated lysine availability. Presumably during processing of cottonseed meal, the heat applied to the meal induced changes in the peptide chain and lysine molecule that had little effect on digestibility but rendered the absorbed lysine less available. This is consistent with reports in the literature that have shown that the fall in biological value of a protein subjected to heat is much greater than can be explained by the decrease in the ileal digestibility of lysine (e.g. Hurrell et al. 1976). Similarly, Craig \& Broderick (1981) found that, as heat was applied to cottonseed meal, there was a greater decrease in the fluorodinitrobenzene-available lysine content than of the true digestibility of the protein for rats. A number of studies have investigated possible reactions between lysine and other amino acids or reducing sugars to explain this effect. For example, Bjarnason \& Carpenter (1969) found that $\epsilon$ - $N$-propionyl-L-lysine, a derivative of lysine induced by heat, is absorbed by rats but inefficiently utilized. Furthermore, this effect was species specific as it is utilized by chicks (Varnish \& Carpenter, 1975). Ford \& Shorrock (1971) also reported that small peptides may be absorbed from heat-damaged protein and these peptides had reduced nutritional value. Hurrell et al. (1976) studied the nutritional value of isopeptides formed by heat; these compounds appeared to be digested, but it was not clear to what extent they contributed to the nutritional value of the protein. They hypothesized that isopeptides may be absorbed and subsequently deaminated. It is apparent from the previously mentioned and other studies that heat applied to proteins can induce changes to the form in which amino acids such as lysine are digested and absorbed. However, because of analytical difficulties in measuring these compounds and tracing their subsequent absorption and metabolism, it is difficult to quantify these effects.

Overall, the results indicate that, for meals of high quality, there is close agreement between ileal digestibility and lysine availability. However, in meals of low availability, ileal digestibility overestimated availability. Thus, diets need to be formulated on an available amino acid basis. Whilst the availability of lysine can be used to estimate the availability of the other essential amino acids, there is a need to verify whether separate determinations are warranted.

The authors are grateful to Messrs N. R. Thompson and A. W. Davis for management of the pigs and skilled technical assistance; Mr R. F. Lowe and Ms B. V. Burnham for chemical analyses; Ms E. White for statistical analyses and Cargill Oilseeds, Australia, for 
supply of cottonseed meal and gossypol analyses. This work was supported by financial grants from the Pig Research Council.

\section{REFERENCES}

Agricultural Research Council (1981). The Nutrient Requirements of Pigs. Slough: Commonwealth Agricultural Bureaux.

Allen, E., Johnson, A. R., Fogerty, A. C., Pearson, J. A. \& Shenstone, F. S. (1967). Inhibition by cyclopropene fatty acids of the desaturation of stearic acid in hen liver. Lipids 2, 419.

Baligna, B. P. \& Lyman, C. M. (1957). Preliminary report on the nutritional significance of bound gossypol in cottonseed meal. Journal of the American Oil Chemists' Society 34, 21.

Batterham, E. S. (1979). Lupinus albus cv. Ultra and Lupinus angustifolius cv. Unicrop as protein concentrates for growing pigs. Australian Journal of Agricultural Research 30, 369-375.

Batterham, E. S., Andersen, L. M., Lowe, R. F. \& Darnell, R. E. (1986). Nutritional value of lupin (Lupinus albus)-seed meal for growing pigs: availability of lysine, effect of autoclaving and net energy content. British Journal of Nutrition 56, 645-659.

Batterham, E. S. \& Murison, R. D. (1981). Utilization of free lysine by growing pigs. British Journal of Nutrition 46, 87-92.

Batterham, E. S., Murison, R. D. \& Andersen, L. M. (1984). Availability of lysine in vegetable protein concentrates as determined by the slope-ratio assay with growing pigs and rats and by chemical techniques. British Journal of Nutrition 51, 85-99.

Batterham, E. S., Murison, R. D. \& Lewis, C. E. (1979). Availability of lysine in protein concentrates as determined by the slope-ratio assay with growing pigs and rats and by chemical techniques. British Journal of Nutrition 41, 383-391.

Bjarnason, J. \& Carpenter, K. J. (1969). Mechanisms of heat damage in proteins. 1. Models with acylated lysine units. British Journal of Nutrition 23,859 868.

Burlacu, G., Baia, G., Ionila, D., Moisa, D., Tascenco, V., Visan, I. \& Stoica, I. (1973). Efficiency of the utilization of the energy of food in piglets after weaning. Journal of Agricultural Science, Cambridge 81, $295-302$.

Campbell, R. G., Taverner, M. R. \& Rayner, C. J. (1988). The tissue and dietary protein and amino acid requirements of pigs from 8.0 to $20.0 \mathrm{~kg}$ live weight. Animal Production 46, 283-290.

Craig, W. M.\& Broderick, G. A. (1981). Effect of heat treatment on true digestibility in the rat, in vitro proteolysis and available lysine content of cottonseed meal protein. Journal of Animal Science 52, 292-301.

Finncy, D. J. (1964). Statistical Method in Biological Assay, 2nd ed. London: Griffin.

Ford, J E. \& Shorrock, C. (1971). Metabolism of heat-damaged proteins in the rat. Influence of heat damage on the cxcretion of amino acids and peptides in the urine. British Journal of Nutrition 26, 311-322.

Hughes, G. J. \& Wilson, K. J. (I982). Amino acid analyses using isocratic and gradient elution modes on Kontron AS-70 $(7 \mu \mathrm{m})$ resin. Journal of Chromatography 242, 337-341.

Hugli, T.E. \& Moore, S. (1972). Determination of the tryptophan content of proteins by ion exchange chromatography of alkaline hydrolysates. Journal of Biological Chemistry 247, 2828-2834.

Hurrell, R. F., Carpenter, K. J., Sinclair, W. J., Otterburn, M. S. \& Asquith, R. S. (1976). Mechanisms of heat damage in proteins. 7. The significance of lysine-containing isopeptides and of lanthionine in heated proteins. British Journal of Nutrition 35, 383-395.

Jordan, J. W. \& Brown, W. O. (1970). The retention of energy and protein in the baby pig fed on cows' milk. In Energy Metabolism of Farm Animals, pp. 161-164 [A. Schurch and C. Wenk, editors]. Zürich: Juris.

Leibholz, J. (1986). The utilization of lysine by young pigs from nine protein concentrates compared with free lysine in young pigs fed ad lib. British Journal of Nutrition 55, 179-186.

Sauer, W. C. \& Ozimek, L. (1986). Digestibility of amino acids in swine: results and their practical applications. A review. Livestock Production Science 15, $367-388$.

Standing Committee on Agriculture (1987). Feeding Standards for Australian Livestock. Pigs. East Melbourne: CSIRO.

Tanksley, T. D. \& Knabe, D. A. (1981). Use of cottonseed meal in swine rations. Feedstuffs 53, 24-27.

Taverner, M. R. (1982). Nutritive value for pigs of white lupins (L. albus cv. Hamburg). Proceedings of the Australian Society of Animal Production 14, 667.

Taverner, M. R., Curic, D. M. \& Rayner, C. J. (1983). A comparison of the extent and site of energy and protein digestion of wheat, lupin and meat and bone meal by pigs. Journal of the Science of Food and Agriculture 34, $122-128$.

Taverner, M. R., Hume, I. D. \& Farrell, D. J. (1981). Availability to pigs of amino acids in cereal grains. 2. Apparent and true ileal availability. British Journal of Nutrition 46, 159-171.

Varnish, S. A. \& Carpenter, K. J. (1975). Mechanisms of heat damage in proteins. 5. The nutritional values of heat-damaged and propionylated proteins as sources of lysine, methionine and tryptophan. British Journal of Nutrition 34, 325-337. 